\title{
School Improvement and Contextual Factors: A Qualitative Case Study on Educators' Perceptions and Experiences
}

\author{
Mahmut Kalman ${ }^{1 *}$ \\ ${ }^{1}$ Gaziantep University, Faculty of Education, Department of Primary Education, Gaziantep, TURKEY \\ *Corresponding Author: mahmutkalman@gmail.com
}

Citation: Kalman, M. (2020). School Improvement and Contextual Factors: A Qualitative Case Study on Educators' Perceptions and Experiences. Pedagogical Research, 5(4), em0083. https://doi.org/10.29333/pr/9134

\begin{abstract}
ARTICLE INFO
Received: 8 Jul. 2020

Accepted: 3 Sep. 2020

ABSTRACT

The present study focuses on the exploration of the perceptions and experiences of school administrators (principals and vice-principals) and teachers regarding school improvement and influencing contextual factors. Designed as case study research, this study utilized data gathered from school principals, vice-principals, and teachers from various school levels in the fall semester of 2019-2020 academic year. The researcher collected data in a graduate-level course offered in a master's program without a thesis at a large state university in Southeastern Turkey through course assignments. Delving into school improvement perceptions and experiences from the eyes of three different groups of practitioners offered significant insights into contextual factors, namely hindrances to and enablers of school improvement, along with the steps to be taken at the praxis level and certain external factors. The results of the research might indicate that both issues related to the human side of school improvement such as the behaviors, practices, and attitudes of school staff, students and parents and the structural side like physical characteristics, budget, education system, and socioeconomic status of school environment have impacts on school improvement. These factors are likely to govern school improvement efforts and outcomes.
\end{abstract}

Keywords: school improvement, contextual factors, educator perceptions and experiences, qualitative research

\section{INTRODUCTION}

Reform and change are essential in education for both improving schools and re-building educational systems to attain more quality school outcomes. Centering on cultivating quality school outcomes, school improvement (hereafter SI) is considered to be "a distinct approach to educational change that aims to enhance student outcomes as well as strengthening the school's capacity for managing change" (Hopkins, 2001, p. 13). As a complex process, SI covers school-level changes initiated to affect student learning positively (Feldhoff, Radisch, \& Bischof, 2016) and requires a collaborative effort that depends on culture and climate that supports growth and learning for teachers and the organization (Zepeda, 2013). SI refers to a systematic way of generating change and development within the schools (Harris, 2002) and makes inquiries on how to enhance student achievement through focusing on the teaching-learning process and the conditions that support this process (Hopkins, 2001) because student achievement can be considered to be one of the most important indicators of school quality and learning process outcomes (Şen, Yıldırım, \& Karacabey, 2020). The present research aims to explore what contextual factors, more precisely the influencing elements at the school level, have impacts on the improvement of the schools through a case study. After an initial overview of what SI means and targets, prior work on SI and related issues are presented in the following section.

\section{LITERATURE REVIEW}

Research on SI underlines the significance of changing key organizational processes and focusing on SI in context to get profound information about transformational processes (Harris, 2020). Changing internal conditions and building capacity for development is considered to be critical for SI (Hopkins, Harris, \& Jackson, 1997). A substantial body of research on SI places a strong emphasis on capacity building and school contexts. Capacity building makes a difference in getting desired results because not possessing such a capacity can preclude schools from sustaining continuous SI efforts that result in improved student outcomes (Hopkins \& Reynolds, 2001). Therefore, Harris (2011) underscores the importance of deliberate, purposeful, and targeted capacity building for the realization of change initiated. According to King and Bouchard (2011), school capacity consists of five interrelated dimensions that affect the quality of instruction and student achievement at schools. These are professional 
community, teachers' knowledge, skills, and dispositions for instruction, program coherence, effective principal leadership, and technical resources. Mincu (2015) refers to the importance of collective capacity building for SI, and she believes this capacity can be built through teacher development and research-derived knowledge. School-based research emphasizing collaboration and inquiry is needed to increase the capacity of schools to bring about positive change because it is a shared responsibility to make school change happen (Constantinou \& Ainscow, 2020). Ateş and Ünal (2019) recommend that each school implement its SI project and thereby transform into a professional learning community. In their case study of a SI project, they revealed that the project constructed a continuous learning environment, became a source of motivation, provided autonomy, and addressed the quest for meaning for teachers.

Some critical characteristics that require a close investigation for SI have been revealed in the literature. To begin with, school culture has been linked to SI. School culture as a critical source of information about the feelings, assumptions, values, and beliefs for shaping a school identity (Stolp \& Smith, 1995) is revealed to be highly significant for SI (Zhu, Devos, \& Li, 2011). Lee and Louis (2019) noticed that schools strongly equipped with the cultural elements, namely academic press, student support, trust and respect, low negativity, and professional learning community showed higher levels of school performance when compared with their counterparts. These cultural elements were revealed to be critical for sustained SI. Consistently, Harris and Jones (2010) point to the dominant school culture which they believe can either support or undermine innovation and change. Fullan (2020, p. 140) implies the need for building such a culture by articulating that "the leaders' job then is to build a culture where people come to embrace a focus on continuous improvement as something they have to do and prove to themselves and others". Cultivating a change-supportive, strong, improvement-oriented, and positive culture can then be considered to be critical for SI.

Another element taken into consideration for SI is school leadership. Leithwood, Harris, and Hopkins (2020) claim that school leadership affects the features of schools, enhances the quality of teaching and learning at schools by referring to its role in the success of most SI efforts to achieve. Likewise, Robinson, Bendikson, McNaughton, Wilson, and Zhu (2017) argue that leadership plays a central role in coordinating improvement efforts at schools. The ultimate goal of educational leadership, as Supovitz, D'Auria, and Spillane (2019) argue, is to attain meaningful and sustainable SI. A burgeoning body of research has evinced the effect of school leadership on positive student outcomes (see Coelli \& Green 2012; Heck \& Hallinger, 2014; Karadağ, 2020; Özdemir \& Yalçın, 2019; ten Bruggencate, Luyten, Scheerens, \& Sleegers, 2012).

School climate has been widely examined as a catalyst for SI, and it predicts the academic, behavioral, and psychological outcomes of students (Wang \& Degol, 2016). According to Thapa, Cohen, Guffey, and Higgins-D'Alessandro (2013, p. 369), school climate reflects school staff's, students' and parents' experiences of school life socially, emotionally, civically, ethically, and academically. They recommend investigating school climate through the perceptions of staff, students, and parents in four aspects of school life which covers safety, relationships, teaching and learning, and the institutional environment. Also, they note that the effect of school climate on school change should be examined as this investigation can help understand SI processes and efforts. In a meta-analysis by Karadağ, İşçi, Öztekin, and Anar (2016), school climate was found to be a significant predictor of student achievement. These research results indicate how the different characteristics of school life can have considerable impacts on SI.

Another critical element is teacher collaboration which also affects SI in a positive way (Hoque, Alam, \& Abdullah, 2011). Teacher collaboration has positive impacts on teacher practices and student learning (Weddle, Lockton, \& Datnow, 2020). According to Aldridge, Rijken, and Fraser's (2020) study, teachers are more likely to think about their classroom actions, evaluate them, and transform their practices when the interactions between them increase. The existence of true collaboration among teachers requires them to become interdependent and share a common vision and responsibility to boost student learning (Ibrahim, 2020). In a similar vein, teacher professional development is linked with SI (Hoque, Alam, \& Abdullah, 2011). Mitchell (2013, p. 390) defines professional development as "the process whereby an individual acquires or enhances the skills, knowledge and/or attitudes for improved practice" and asserts that teacher professional development can constitute SI if it can both improve teacher practices and student outcomes. Poekert (2012) considers teacher leadership to be a form of job-embedded professional development and proposes that teachers must be developed as leaders, which may both enhance student achievement and develop school capacity, thereby linking teacher leadership, professional development, and SI.

The elements provided in the literature review part of this study are not exhaustive. Hopkins (2001) lists the within-school elements associated with the development of schools, some of which were also mentioned above, such as staff development, the involvement of the staff, students and the community in school policies and decisions, transformational leadership, effective coordination strategies, enquiry and reflection, and a commitment to collaborative planning activity. Drawing on the research conducted previously, it is likely to argue that SI can be achieved through the joint efforts and contributions of the school community and that continuous reflection and enquiry about the school practices and operations should always accompany what is done for the development of the school.

\section{CONCEPTUAL FRAMEWORK OF THE PRESENT RESEARCH}

The current research is based on the perspective of Murphy (2013). Viewing SI from a broader perspective, Murphy (2013, p. 257-261) provides a new way of thinking about SI which he calls the architecture of school improvement through a framework consisting of five significant parts: an essential equation, building material, construction principles, enabling supports, and integrative device. The essential Sl equation is laid on academic press and supportive culture (i.e. SI= Academic Press + Supportive Community). Building material covers "identifying and bringing the right materials to the school improvement building site" ( $p$. 258) and refers to the ingredients of SI which have the potential to engender academic press and supportive culture: quality 
Table 1. Demographic information regarding the participants

\begin{tabular}{|c|c|c|c|c|c|}
\hline & Pseudonym & Gender & Age & School type & Position \\
\hline 1. & Salih & Male & 32 & Primary school & Teacher \\
\hline 2. & Arif & Male & 42 & Primary school & Principal \\
\hline 3. & Arda & Male & 44 & Primary school & Vice-principal \\
\hline 4. & Akif & Male & 43 & Primary school & Principal \\
\hline 5. & Burcu & Female & 30 & Middle school & Vice-principal \\
\hline 6. & Cafer & Male & 26 & Middle school & Teacher \\
\hline 7. & Ela & Female & 31 & Primary school & Vice-principal \\
\hline 8. & Emir & Male & 25 & Vocational high school & Teacher \\
\hline 9. & Ekrem & Male & 38 & Primary school & Teacher \\
\hline 10. & Gül & Female & 28 & Primary school & Vice-principal \\
\hline 11. & Hasan & Male & 31 & Vocational high school & Vice-principal \\
\hline 12. & Kevser & Female & 28 & Primary school & Vice-principal \\
\hline 13. & Murat & Male & 49 & Vocational high school & Principal \\
\hline 14. & Melih & Male & 41 & Anatolian high school & Vice-principal \\
\hline 15. & Mustafa & Male & 39 & Primary school & Vice-principal \\
\hline 16. & Necip & Male & 46 & Anatolian high school & Vice-principal \\
\hline 17. & Asaf & Male & 43 & Anatolian high school & Principal \\
\hline 18. & Tuncer & Male & 42 & Primary school & Vice-principal \\
\hline 19. & Derya & Female & 55 & Primary school & Teacher \\
\hline 20. & Sami & Male & 34 & Middle school & Teacher \\
\hline
\end{tabular}

instruction, curriculum, personalized learning environment for students, professional learning environment for educators, learning-centered leadership, learning-centered linkages to the school community, and monitoring of progress and performance accountability. Construction principles involve three ideas: structure does not predict performance, context always matters, and cohesion and alignment are essential. Supports refer to organizational structures, operating systems, policies, and practices. The last part of the framework, the integrative dynamic, is leadership. A comprehensive examination of the elements and features of the school organization is taken into consideration to better understand how schools can improve. Having greater insight into the contextual factors affecting SI would yield useful information about how to help schools attain sustainable improvement because there is still a need for further research on SI in Turkey (Şahin, 2013); therefore, this study may contribute to the existing knowledge base by seeking answers to the following research questions: a) What contextual factors affect the improvement of schools? b) What educational implications can be drawn about SI for praxis?

\section{METHODOLOGY}

The present research was designed as an intrinsic case study (Stake, 1995). The researcher examined the written answers of educators (school administrators and teachers) to dig out the influencing contextual factors with regards to SI in various school settings based on actual perceptions and experiences. As the researcher hoped to gain insights for praxis, it was deemed important to utilize a case study as a design. Case study research makes it possible to gain an in-depth understanding of behaviors, processes, practices, and relationships in context by asking why, how and what questions about the issue under study (Harrison, Birks, Franklin, \& Mills, 2017) via collecting in-depth and detailed data (Creswell, 2013).

\section{Study Group and Demographics}

This study consisted of 20 participants including school principals $(n=4)$, vice-principals $(n=10)$, and teachers $(n=6)$ as the participants who were selected via a purposeful sampling technique. The demographic information regarding the participants is provided in Table 1.

Table 1 indicates the demographic information about the participants. A total of 20 participants constituted the sample of the study. Of the participants, 15 (75\%) were male, and 5 (25\%) were female. 11 participants were from primary schools, 6 from secondary schools (vocational and Anatolian), and 3 from middle schools located in a large province in Southeastern Turkey. More than half of the participants $(n=11)$ were working at primary schools. The participants' ages ranged between $25-55$ years $(\bar{X}=37,35$, $\mathrm{sd}=8,33)$.

\section{The Procedure}

The researcher collected data in a graduate-level master course entitled "School Improvement" which was offered in an educational administration master program without a thesis in a large state university in Southeastern Turkey. The master program lasts 3 semesters, and students who are enrolled have to take 10 courses and write one graduate project to complete the program. The program is open for school principals, vice-principals, and teachers along with those from other sectors having an undergraduate diploma from a four-year program at the tertiary level. The course, i.e. School Improvement, covers topics related to SI, historical background of SI movement, school effectiveness-school improvement (SESI) linkage, SI models, and national and international SI projects and agenda. The course is a theoretical one, and enrolled students receive education in one semester on the abovementioned issues. To turn the course into an evidence-based and practice-informed format, the researcher as the instructor of the course, decided to lead the students to ponder on SI, the contextual issues, and factors affecting SI in primary, 
middle, and secondary school settings. All of the participants were asked to answer the questions included in a form, reflecting their perceptions and concrete experiences. After writing up their answers, all of the participants handed over their documents both via email and as printed copies.

\section{Course Assignments as the Collected Research Data}

The researcher assigned the enrolled educators to prepare a report about their school's improvement and contextual factors by providing them with a research protocol consisting of open-ended questions for the collection of the data at the praxis level. The questions were shared with an expert in educational administration who also taught the same course in a different class during the data collection period, and his opinions were sought about the data collection protocol. Furthermore, a personal information part was added to detect demographic information regarding the participants. The questions included in the form were as follows:

1. Do you believe your school is improving?

a. What indicators reflect your school's improvement?

b. Which indicators do you think indicate that your school is not improving as desired or is maintaining?

2. What factors impede your school's improvement?

3. How is your school's climate? How can a supportive climate for learning be built in your school?

4. What factors hinder your school's success? What should be done to increase success at the school level?

The researcher provided clear instructions about what was expected from the participants while writing about their perceptions of and experiences on the contextual factors affecting the improvement of their school in their reports.

\section{Validity and Reliability}

To ensure validity and reliability in the research, the researcher followed a set of procedures: The questions posed were relevant to the participants' perceptions and actual experiences of SI at their schools. The participants were selected purposefully, and their demographics were presented in detail. The research process was described in detail from start to end. Direct quotations from the participants' views were provided. A constant comparative approach was adopted while coding the data, first by using data analysis software and then reading the transcripts/reports continually. A codebook was used to ensure consistency among the patterns extracted from the data (Saldaña, 2013).

During the report writing process, the researcher remained neutral not to affect what the educators reported. After giving the instructions for the content of the reports expected, the researcher asked the participants to think about their schools and write what was happening there and also to provide evidence indicating the issues mentioned. Almost all of the participants (except for three participants) added photographs regarding their opinions included in the reports.

\section{DATA ANALYSIS}

The researcher obtained the data via the participants' written answers provided in the course assignments. After transferring all of the data to the Quirkos v2.3 software, the researcher tried to code the data considering commonalities and differences between the participants' perceptions and experiences by using thematic analysis. According to Braun and Clarke (2006), thematic analysis is a qualitative analytic method used for identifying, analyzing, and reporting patterns within data. "Thematic analysis produces a depth of understanding of the meaning of a set of texts" (Neuendorf, 2019, p. 219). The researcher followed the sixstep approach to thematic analysis proposed by Braun and Clarke (2006, p.87): Familiarizing with data, generating initial codes, searching for themes, reviewing themes, defining and naming themes, and producing the report, and its implementation in the field of education (Xu \& Zammit, 2020). Based on the participants' perceptions and experiences, themes, subthemes (when needed), and codes were constructed. Representative quotations were presented to directly reflect what was mentioned about the research topic.

\section{FINDINGS}

The researcher compiled the findings of SI and contextual factors, and six main themes were identified and presented in six thematic maps. The main themes were: indicators of improvement, indicators of failure to improve, hindrances to school improvement, perceived school climate and enablers of a positive climate, hindrances to school success, and elimination of barriers to school success. A final map (Thematic Map 7) was formed based on the themes developed to show the intersections between the factors affecting SI. The themes and meaningful patterns offered a comprehensive overview of the contextual factors that were perceived to have impacts on improvement in the school settings.

Regarding the findings of whether the participants believed their schools were improving or maintaining, an intertwining pattern was revealed. Nearly all of the participants considered that in some aspects their schools managed to improve, while in some other ones they could not reach an intended level of improvement. Therefore, instead of making a sharp division between participant perceptions in this sense, the researcher focused on what counts as the indicators of improvement and maintenance. 


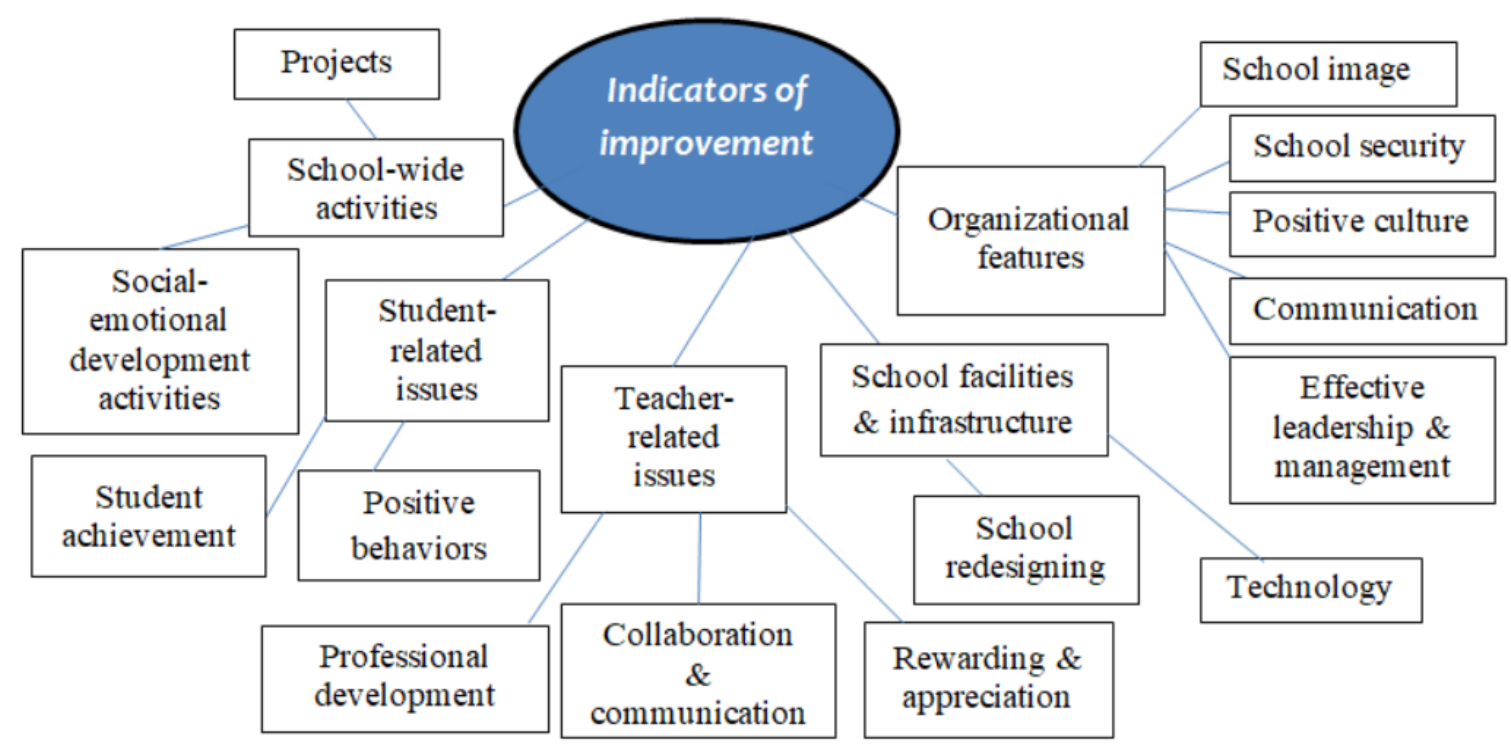

Thematic Map 1. Indicators of improvement

\section{Indicators of Improvement}

The participants reflected their perceptions and experiences regarding their schools' improvement by emphasizing some indicators. Several subthemes that were perceived as the indicators of improvement are provided in Thematic Map 1.

As displayed on the Thematic Map 1, the participants tended to link SI to different aspects such as school-wide activities, teacher-related issues, student-related issues, school facilities, and infrastructure and schools' organizational features. A wide spectrum of indicators was regarded to reflect improvement at schools.

Organizational features were the most mentioned indicators. Effective communication among stakeholders; i.e., teachers, students, administrators and parents, effective school management and leadership, positive school image, positive school culture, and increased security were believed to display that their schools were improving. As an example, Gül wrote what they did at their school: "To improve our school, we carry out studies with school administration, our teachers, and counseling service. We try to increase participation in sports activities. By opening various courses at the school, we attempt to provide more venues for students to express themselves more comfortably."

Some participants viewed the issues concerning teachers and some relational patterns such as collaboration, professional development, strong communication, and rewarding and appreciation as the signs of SI. Those who believed that their school was improving referred to student achievement and the positive behaviors of students as the main indicators. Regarding this issue, Cafer wrote: "One of the greatest indicators of our school's improvement is student achievement. Last year our school ranked as the most successful school in the district in the transition to high school exam (LGS). Also, our students received some degrees due to ranking as the first and second in the chess tournament against those from private schools last year. Our school has been selected as the pilot school in many projects in our province."

Ela noted:

When children from multi-child families see the interest that their families do not show from teachers and school administration, they feel more worthful and warn their friends not to give physical harm to school facilities (dying the walls, slamming the door, etc.). We make an effort to develop values in students. For example, we greeted students by saying "good morning" since the first day of the school. Even though they did not respond to us, we continued to do that. Over time, one, two, three, four students... a majority of them started to greet us by saying "good morning" before we say. Albeit being a little thing, cultivating such behavior in students can be an example of school improvement.

It was revealed that schools' organizing school-level activities targeting developing students' emotional and social development through sportive, artistic, cultural, and social activities and producing school-based projects were perceived as improvement-related indicators as well. Lastly, some participants underscored the redesigning of school facilities and infrastructure involving arrangements in school buildings and gardens and strengthening technological infrastructure. Melih mentioned the arrangements in his school: "We detected the problems related to the school building caused by poor workmanship on time and found solutions to these problems to minimize expenditures before turning into a large-scale waste of money."

As the findings implied, the participants adopted a comprehensive overview regarding $\mathrm{SI}$ and influencing factors by emphasizing both the human side and structural aspects of schools.

\section{Indicators of Failure to Improve}

The second major finding was related to the signs or outputs that reflect schools' failure to improve at the desired level. The participant views were gathered under five subthemes: inadequate school finance and infrastructure, lack of parental support, 


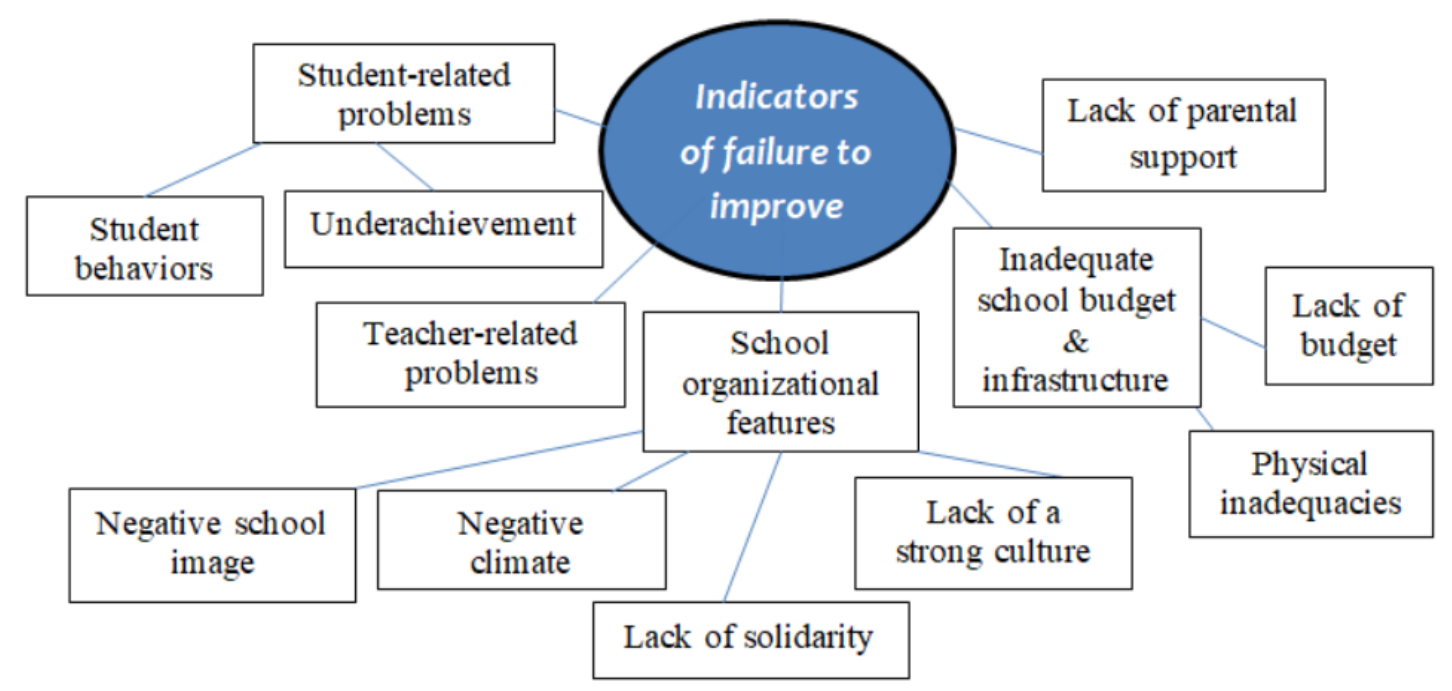

Thematic Map 2. Indicators of failure to improve

negative organizational features, teacher-related problems, and student-related problems. Thematic Map 2 shows the pattern of influencing contextual factors at school settings under investigation.

According to the participants' views, students' misbehavior and underachievement were the most notable outputs reflecting their schools' failure to improve at the desired level. Sami noted that: "There are still some students at our school, not that much though, who leave school before or after attending high school." Negative organizational features of the schools such as negative climate, negative school image, weak culture, and lack of solidarity were identified as the indicators of lack of improvement as expected. Some argued that their schools could not improve due to the lack of school budget and physical inadequacies. These problems were reported to have minimized their taking action for improvement. For example, Derya wrote: "It is too hard for students to reach resources due to financial problems in our school. The resources and test books we want cannot be afforded, and this lowers our students' achievement."

At some schools, parental support was perceived to be inadequate, and they opined that without parents' involvement and support, schools could not improve. The role of teachers was mentioned in all of the themes as teachers were considered to be the centerpiece of improving schools. Teachers' lack of motivation to teach and produce, not guiding students, taking medical reports frequently, getting to classes late, and inconsistencies between teachers' instructional implementations were specified as the signs of failure to improve or maintenance. Necip summarized the indicators of maintenance: "These are: not ensuring parents' active participation, the increasing number of absent students, lack of organizational culture, teachers' low participation in projects, and the increasing number of teachers getting medical reports..."

\section{Hindrances to School Improvement}

Another significant finding that emerged in the data analysis highlighted the contextual factors negatively influencing SI. Participant views demonstrated the perceived barriers to SI by reflecting a broad spectrum of factors: system-related issues, teacher-related issues, the lack of parental involvement, negative organizational features, student-related issues, and school environment. Thematic Map 3 displays the perceived hindrances to SI.

The most often addressed hindrance was related to teacher behaviors such as closeness to development, tiredness, impassiveness, lack of collaboration and communication with students and some wider issues about the teaching profession and teachers such as lack of respect for teachers, inexperience, failure to integrate technology, and lack of professional development activities. Regarding teacher behaviors and attitudes, Salih commented: "...The attitudes of teachers who are closed to development... Some teachers always articulate that the school must improve but take no steps to attain that."

Some participants believed that parental involvement and support were not satisfactory. The organizational features of schools including school location, school management, negative culture and climate, the intensity of bureaucratic tasks, and inadequate school buildings and space such as having a small garden and lack of laboratories, and the lack of school budget affected the improvement of schools negatively. Burcu opined that: "I want to write about school maintenance (non-improvement) as I believe that my school is not improving. Teachers come to school to fill their course hours and they do not want to take on extra responsibilities. I do not think teachers are responsible for this conduct; if we were to offer them a school climate that can help them develop, they would not come here just for filling their course hours." 


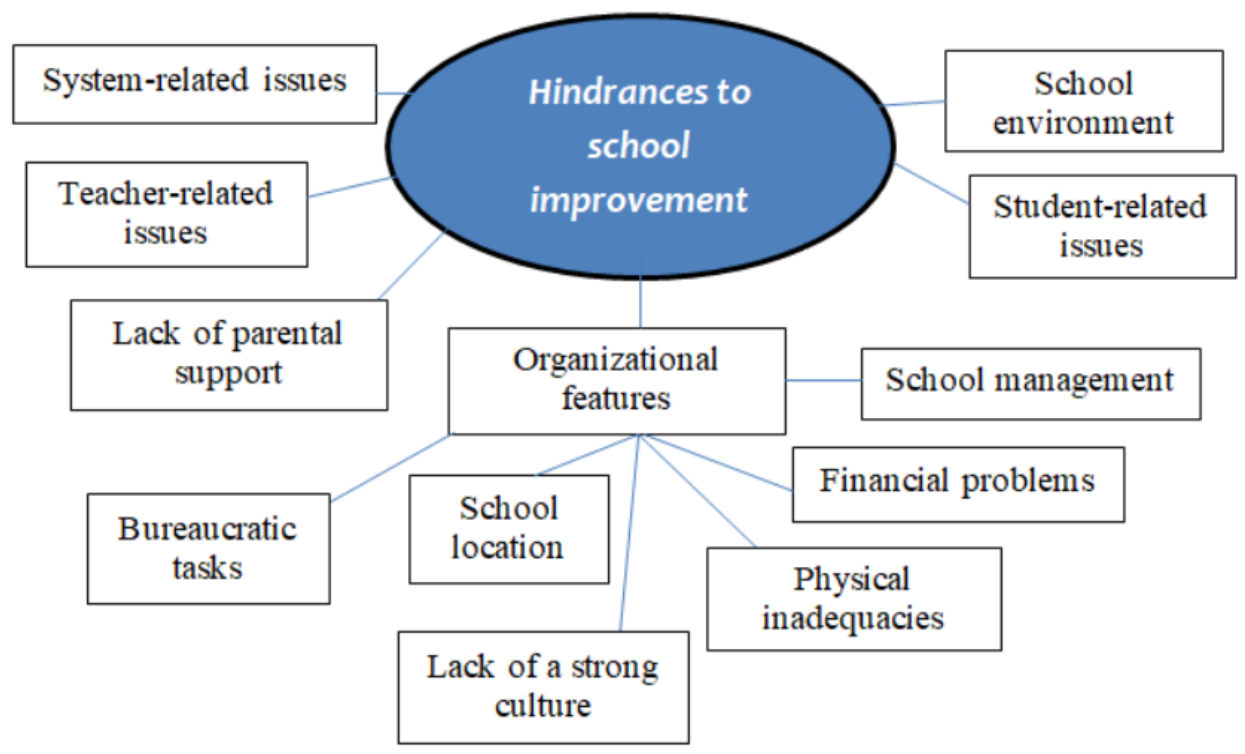

Thematic Map 3. Hindrances to school improvement

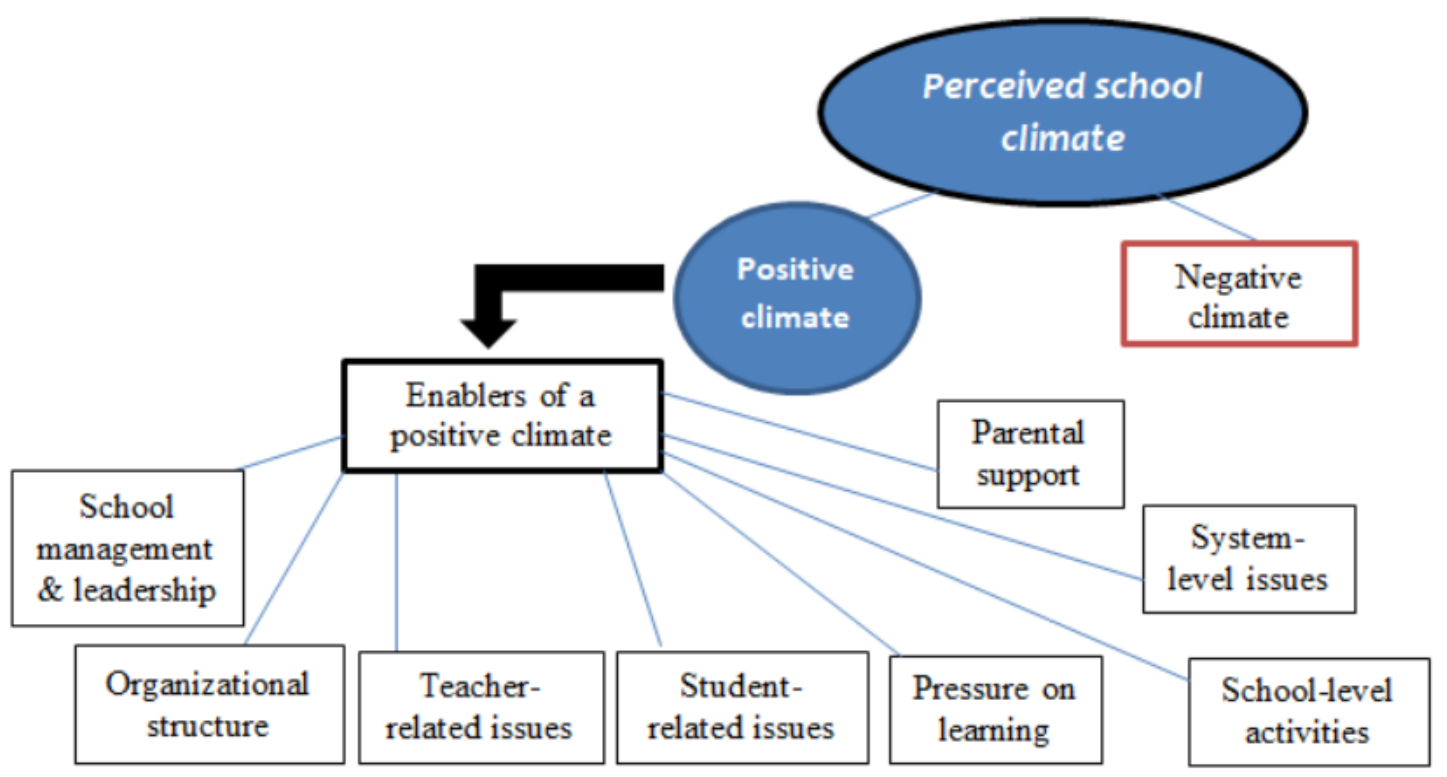

Thematic Map 4. Perceived school climate and enablers of a positive climate

A small group of participants mentioned school administrators' unsupportive behaviors and inability to exert leadership. The school environment that some schools were located in was socio-economically disadvantaged, and this made getting parents' support, especially financially, hard. The last issue noted was related to students. Some participants argued that student misbehavior such as bullying, truancy, irresponsibility, lack of engagement, low profile, and high student quota prevented their schools from achieving improvement. Asaf, a principal, commented: "A school principal cannot choose teachers, students, and even support personnel. He tries to keep students who have nothing with education at school." The high number of students was reported to decrease instructional quality. At three schools, there were a large number of Syrian refugees, which the participants from these schools regarded as a barrier to improvement because of the imbalanced distribution of these students to their schools and specific problems faced such as language. Arda wrote: "In the last 3 years, Syrian students have come to our school intensively (over 800); this downgraded our school firstly academically and then physically and retarded SI partly."

\section{Perceived School Climate and Enablers of a Positive Climate}

Thematic Map 4 indicates how school climate was perceived by the participants and what they thought would enable the construction of a positive climate supporting learning. A bipolar division of school climate perceptions was observed.

The participants shared their perceptions and experiences regarding school climate which could be categorized as positive and negative based on the characteristics focused on. For the negative climate, the participants underlined the aspects such as being very formal, not good, cold, closed, and passive, whereas the ones proposing that their school climate was positive pointed out to the aspects such as being warm, supportive, participative, intimate, and nice. The participants were observed to describe their school's climate based on the relationships between school staff (teachers and administrators) and students, engagement, and commitment. Tuncer, for example, wrote: "Most of our teachers have completed half of their professional life by retirement age, 


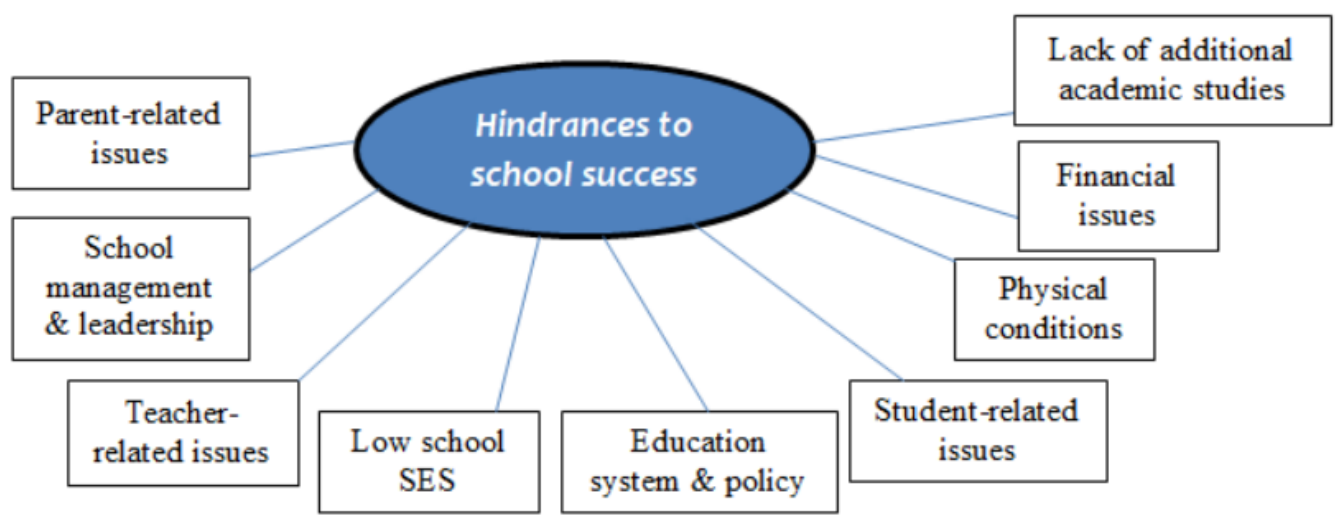

Thematic Map 5. Hindrances to school success

and they guide novice teachers appointed to our school. Novice/young teachers help the older ones for technology use. We can talk of an environment supporting learning, even if not entirely so." However, as a negative example, Kevser stressed that: "In our school, there is an administration which is close to new ideas; teachers are far from assistance and solidarity. There are schismatic student, teacher, and management groups. Some students and teachers look forward to the end of the courses. They are passive in social activities."

The second part of this theme consisted of the participants' views about the enablers of the formation of a positive climate at schools. Some educators stressed the importance of school administrators' being instructional leaders and supportive. However, a special role was attributed to teachers. Most of the participants argued that teachers' motivation, commitment, and spirituality must be bolstered. Furthermore, teachers must have a say at school, and collaboration and solidarity must be nurtured among teachers. It was asserted that eliminating teachers' tiredness and impassiveness could be valuable for the formation of a positive climate. Hasan asserted that: "The general weariness and reluctance of teachers does not result from the school administration or environment but their academic education. Dispersing the negative climate in our school can be only possible by training which nurtures teachers'spiritual aspects." He questioned teacher education in terms of teachers' spirituality.

Meeting the social needs of the school staff through social activities, forming an open and transparent organizational structure, making system-level adjustments like giving up the supply of school books for free, motivating students and making them feel happy at school, getting parental support and exerting an academic pressure on learning and development were the aspects written down for the formation of a positive climate. Regarding how to form a positive climate, Ekrem wrote: "To build $a$ school climate supporting learning, attention must be paid to academic learning and development. Positive relationships must be built among students, and parents' involvement and support must be ensured."

\section{Hindrances to School Success}

The participants' perceptions and experiences about the factors that impeded school success were gathered under the hindrances to the school success theme. Varying aspects that influence school success were emphasized. Thematic Map 5 displays the barriers to school success as perceived by the participants.

As demonstrated in Thematic Map 5, the participants pointed out to multifold factors ranging from macro-level factors such as education system and policy to school-level factors such as school leadership and management, teacher-related issues, student-related issues, problems regarding school physical conditions and budget, and insufficient academic studies and school environment characteristics such as low socio-economic status and lack of parental involvement and support. Among the factors delineated, two factors came to the forefront, issues related to teachers and students, while others such as parental involvement and support, problems of school physical conditions and budget, school environment and system-level influencing factors were underlined to be significant too.

Regarding teacher-related issues, varying aspects of teacher attitudes and work behaviors were reported: closeness to development, not using their knowledge and experiences sufficiently, balkanization and miscommunication, not making enough efforts, frequent teacher circulation, late retirement age, not being able to use ICT, and lack of encouraging teachers for generating projects. Emir stressed the problems about teachers: "I believe teachers are still not productive and inclined to work. This year I have become the head of my teaching branch. If I speak for my group, I could not see teachers' carrying out the tasks given or making efforts for SI, unfortunately. This makes me sorry as a teacher."

As one of the main elements causing low success at school, the participants underlined students' lack of purpose, negative standpoints about education, demotivation, a tendency to violence and bullying, and negative attitudes towards school. Another issue noted with regards to students was the high number of Syrian refugees at schools. Furthermore, parental involvement and support were denoted to be insufficient and argued to be a barrier to $\mathrm{SI}$ and success. Considering the issue of school success from a broader perspective, some participants mentioned the role of the education system and policy in getting undesired results in school success. They believed that these macro-level issues also precluded schools from being successful through prioritizing exams over students' cultural and social development, insufficient curricula, the policy of forgiving absenteeism, and the right to school transition during the school year. As for national exams, Ekrem noted: "Schools' success is evaluated based on exams only. Schools are not places where only cognitive skills are taught. Apart from these, affective and psychomotor skills are nurtured. Thus evaluating SI just based on academic achievement is one of the greatest barriers." 


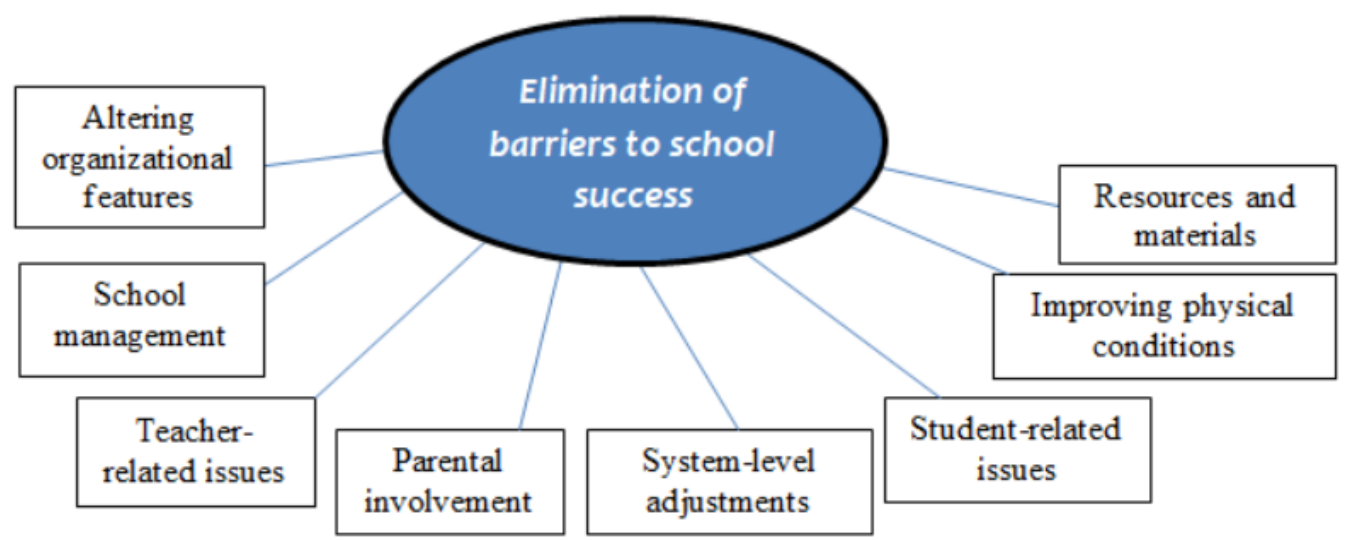

Thematic Map 6. Elimination of barriers to school success

Another influencing factor was revealed to be inadequate physical conditions of schools that were claimed to minimize what schools could do for the development of students. Lack of laboratories, libraries, and spacious school gardens was stressed. Akif, a principal, underlined the effect of school physical characteristics: "The fact that our school's inadequate physical environment, double-shift education, and the inadequate school garden prevent us from improving our school. We have to postpone many activities that we want to carry out at school due to these inadequacies." For some schools, however, one of the most thought-provoking factors was school administrators' inability to exert leadership and develop a vision and not having sufficient power. The socioeconomic status and characteristics of the school environment were also among the influencing factors; the participants from the schools located in low SES environments pointed out to poverty, broken families, and substance use as the barriers to school success.

\section{Elimination of Barriers to School Success}

The last emerging theme was about how to eliminate the perceived barriers to school success. Thematic Map 6 provides the actions to be taken or issues to be adjusted at schools to eliminate the barriers to success.

It was revealed that the participants' suggestions centered on the solutions akin to the ones proposed for SI above. As SI requires making schools better places for students' achievement and learning through appropriate adjustments and projects, the participants were observed to underline almost the same factors for both improvement and achievement. It was noticeable that the main actors of schools, namely teachers, students, parents, and administrators were conceived of as the drivers of school success because most of the suggestions were about increasing quality in the work and behavior of these actors and getting their support.

Among these actors, there were suggestions about teachers and teacher education and development. Some participants underlined the importance of adjusting to school climate, organizing professional development activities for teachers, enhancing teacher prestige in the community, and eliminating the factors demotivating teachers such as economic concerns and violence against teachers. Arif wrote: "As our teachers are inexperienced and highly energetic, in-service training activities can be organized for their professional development by contacting relevant institutions."

The participants stressing the role of parents pointed out that it is important to raise parents' awareness about educational involvement and ensure their involvement at a high level. Several suggestions were made concerning students. These were related to constructing additional opportunities for social and cultural development and academic achievement, guidance services and mindfulness activities, decreasing absenteeism, collaboration between school staff, and making arrangements for Syrian refugees such as offering language courses on the weekends. Mustafa noted that: "Additional courses can be provided for students who are underperforming at the school level. We try to provide opportunities for our students who cannot participate in many sports activities. We open courses in various branches such as folk dance and athletics for talented students."

The leadership of school administrators and positive organizational features were also mentioned to make schools more successful. Regarding the role of school principals, Murat commented: "The school principal must form an ideal school culture for his/her school first of all. It should not be an unplanned and disordered one. It should be kept in mind that the elements constituting the school take place in the culture to be formed." At the system level, too, three participants referred to making some adjustments such as disposing of compulsory secondary education, rearranging transported education for equality of opportunity, and distributing refugee students to schools proportionally. Once more, some participants emphasized the need for arranging or redesigning school facilities and infrastructure to enhance school success.

Based on the overall findings, some implications were drawn regarding the factors affecting $\mathrm{SI}$ at the schools under investigation. Although the main focus of the research was about gaining an understanding of contextual factors affecting SI, it was revealed that certain external factors also come to the point. These contextual (internal) and external factors are summarized in Thematic Map 7. 


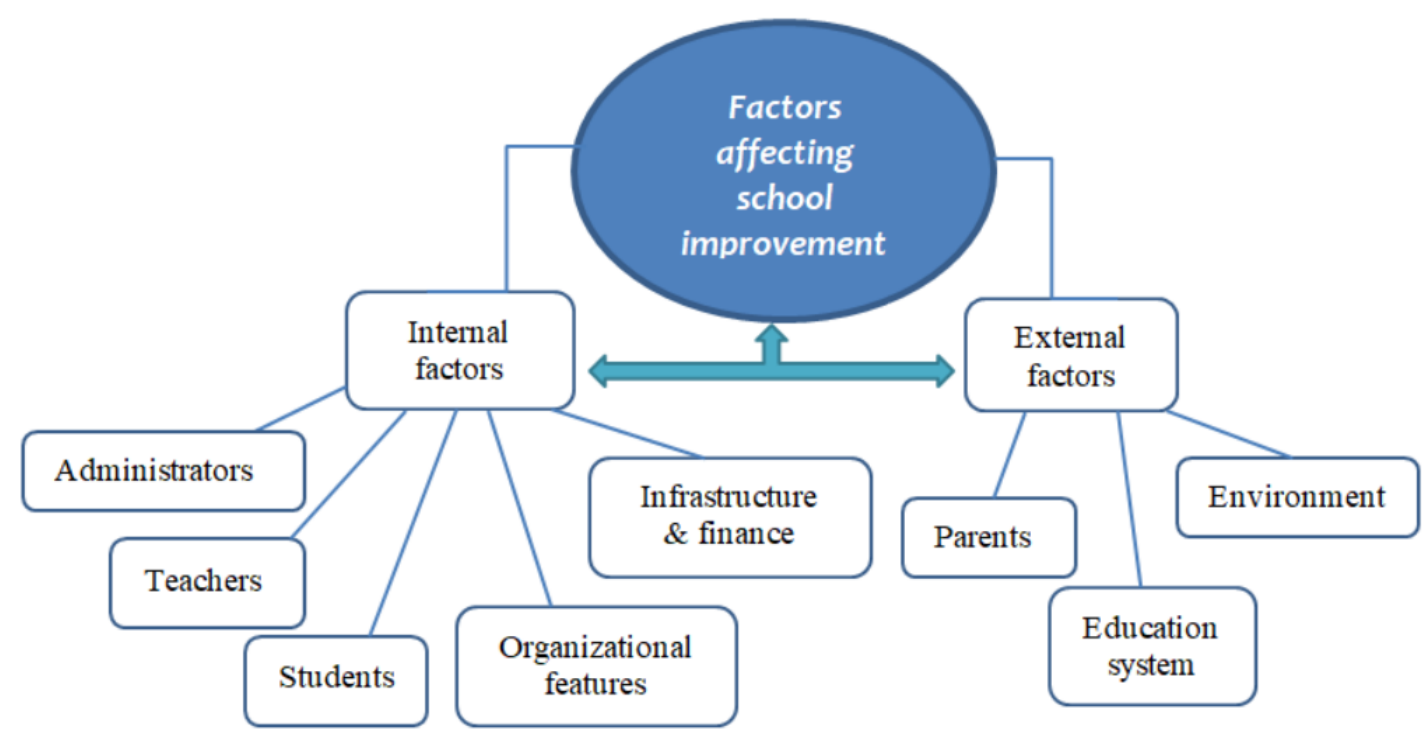

Thematic Map 7. Factors affecting school improvement

The internal factors involved teachers, administrators, and students along with organizational features of schools such as culture, climate, collaboration, solidarity, and image, and school infrastructure and finance. On the other hand, parents, school environment, and the education system were labeled as external factors. However, internal factors interrelate with external ones as schools operate in a dynamic pattern influenced by various elements. Teacher and administrator characteristics and attitudes, student composition, technical resources, and features of the school organization affect the quality of school outcomes. Furthermore, the centralized education system affects schools directly as the budget, human resources, and technical resources are provided by the system in Turkey. Schools are not disconnected from their environments and are heavily shaped by them; therefore, the factors are presented in an interactive fashion on the map.

\section{DISCUSSION AND CONCLUSION}

This study set out to reveal the contextual factors that affect SI based on the reports written by school administrators and teachers from different school levels. Six themes were identified from the data, reflecting the perceived indicators that were considered to show either the schools were improving or not improving as expected based on the participants' standpoints along with hindrances to SI, perceived school climate and enablers of a positive school climate, barriers to school success and suggestions on how to eliminate the barriers to school success. The findings revealed had the potential to shed some light on the influencing contextual factors at the praxis level as the participants were asked to write down their perceptions and actual experiences. When the indicators of improvement and maintenance were examined, it was observed that the participants portrayed SI from a broader perspective featuring the human aspect of the school organization such as students, teachers, parents and school administrators, the structural aspects with soft elements such as positive image, climate, culture, collaboration and hard elements such as appropriate school facilities and strong infrastructure in terms of having spacious gardens, libraries, laboratories, playgrounds, and technological base. As it is deemed significant to examine school-level factors to reveal what affects student achievement and learning outcomes (Oldaç \& Kondakçı, 2019), this study attempted to understand school-level contextual factors affecting SI. However, certain external factors appeared to influence SI as schools in Turkey operate in a highly centralized system.

The findings of the research related to the human side of SI can be categorized as the behaviors, practices, and attitudes of staff, students, and parents. One of the most emphasized elements was teacher attitudes and characteristics along with teacher education and the teaching profession. The participants repeatedly underlined the role of teachers in SI. Some negative behaviors and attitudes, based on participant views, such as closeness to development and collaboration, impassiveness, and weariness were seen as damaging factors in terms of SI. These findings are consistent with past research which links teacher development and collaboration for SI (Hoque, Alam, \& Abdullah, 2011; Mitchell, 2013; Poekert, 2012). However, building collaboration as intended is challenging due to the complexities regarding policies, relationships, and infrastructure to support collective work (Weddle, Lockton, \& Datnow, 2020). In the current research, teacher development and collaboration were deemed to be insufficient as well as teacher motivation. Teacher motivation is associated with student motivation and teacher effectiveness (Han \& Yin, 2016); therefore, enhancing teacher motivation may make positive impacts on student motivation, which some participants were compliant with, and teaching practices.

Interestingly, most participants, especially those from high schools, considered student-related characteristics as barriers to improvement. Misbehaviors among students such as bullying and substance use, lack of expectation from education, demotivation, low profile, etc. were among the issues perceived to impede improvement. The participants from high schools strongly underlined the problems related to students, some of which were low profile/performance, absenteeism, disciplinary problems, demotivation, and reluctance to take on the responsibility of learning. It was believed by the participants that students 
and their characteristics played a significant role in attaining SI. These issues have connections with student attitudes towards schools. Student attitudes towards school may include a wide range of in-school and out-of-school elements such as family and peer groups, classroom learning environment, teacher-student relationship, the evaluation of students' academic work, feelings of loneliness, belongingness and school image (Şeker, 2011, p. 255). In a study by Sezgin, Koşar, Koşar, and Er (2016), it was unearthed that low-performing/unsuccessful high school students confront such problems as absenteeism, discontinuing education, or school drop-out.

One aspect mentioned to make schools improve and successful was effective school leadership and management. This point was delineated from two different aspects, in one aspect some participants complained about school administrators' not being capable of leadership, and in another aspect, some participants underlined limited power and heavy workload as the barriers to exerting leadership and managing schools effectively. Although the effect of school leadership on student outcomes is widely known (see Garza, Drysdale, Gurr, Jacobson, \& Merchant, 2014; Leithwood, Sun, \& Schumacker, 2019), there are some barriers for principals to exert this effect. In recent studies on the Turkish context, it was unearthed that school principals believed that they are civil servants and pettifoggers because their responsibilities are greater than their authority. They opined that bureaucratic processes restrict them, leave no room for them to act freely, confine them to some roles and disable them to get out of these roles (Yalçın, Aypay, \& Boyacı, 2020). The centralized structure of and bureaucratization in the education system in Turkey make it hard for school principals to transform their traditional managerial roles and approaches (Belenkuyu, Dulay, \& Aypay, 2020). Consistently, Yeigh, Lynch, Turner, Provost, Smith, et al. (2019) found that school principals' spending most of their time on solving non-teaching problems and administration was regarded as an impediment to academic performance. Drawing on this evidence, it may sound reasonable to consider the practices of school principals for improving schools in the light of both internal and external arrangements and influences as put by Nehez and Blossing (2020). Nehez and Blossing (2020) revealed that both the governance of a school and education system-level practices such as reforms both shape and constrain school principals' improvement efforts. Furthermore, Klein and Schwanenberg (2020) point to the role of principals in SI by paying attention to this fact: "in several European countries, the role of the principal has traditionally been rooted in governance contexts that were focused on functionality and ordinance rather than on measurable outcomes and improvement, in which principals were little more than teachers with additional administrative tasks" (p. 2). A rather similar fact is true of Turkish school principals. Turkish principals are now expected to lead SI with a strong focus marked in Vision 2023 large-scale reform (MoNE, 2019). On the other hand, some participants believed that school principals were not eligible for exerting leadership. One reason for that may relate to the assignment, selection, and training of school principals. In the current approach adopted in Turkey, it seems unlikely to select those eligible for exerting leadership at schools (Kalman, Summak, \& Çimen, 2017).

One interesting finding was related to the issue of parental involvement and support. The participants did not denote parental involvement and support among the indicators reflecting that schools were improving, which may have resulted from the lack of parental involvement and support. The participants brought parental involvement and support to the fore concerning all of the barriers to $\mathrm{SI}$ and success and suggestions on how to promote improvement and success. Parental involvement in education is believed to promote the learning process (Desforges \& Abouchaar, 2003; Epstein, 2001). Related research reported a significant relationship between parental involvement and overall academic achievement (Jeynes, 2005). However, socio-economic factors set barriers in terms of parental involvement in Turkey. Recent work indicated that socioeconomic status had a measurable and significant impact on the academic performance of students at the middle school level (Suna, Tanberkan, Gür, Perc, \& Özer, 2020). In a similar vein, international research highlights the role of parental involvement in student outcomes. For example, it was found that family SES emerged as the most relevant predictor of academic achievement in Language and Mathematics in Chile (Gubbins \& Otero, 2019). There was a significant positive relationship between parental involvement and achievement in East Asian countries (Kim, 2020). Taken together, it may be asserted that school-level improvement efforts can be successful with the involvement and support of parents. The participants in the current study viewed parental involvement and support as a trivet of SI.

School climate was believed to be important for SI. In some schools, the climate was conceived of as positive and supportive; in some schools, however, the participants were dissatisfied with the existing climate. A recent study by Calp (2020) revealed that what students and teachers believed to be necessary for a positive learning environment: the needed characteristics were feeling valued, good relationships, safety, love, respect, tolerance, happiness, having fun, and positivity. Mitchell, Bradshaw, and Leaf (2010) propose that it is significant to evaluate both teacher and student perceptions of school climate especially when tracing the outcomes of SI initiatives as they can provide information about at school and classroom levels. Therefore, making schools improve necessitates the construction of a positive and strong climate. The participants placed a strong emphasis on organizational behaviors including communication, collaboration, motivation, commitment, spirituality, and solidarity on the part of teachers and students. There were suggestions for the organizational structuring of schools and system-related amendments. The pressure for learning and getting parental support were among the suggestions.

Many participants emphasized the effects of the SES of the school environment. They regarded this as a barrier to improving student outcomes and promoting parents' involvement. Although school SES affect student achievement, Hoy (2012) argues that challenging and attainable goals and cooperation among stakeholders lead to strong motivation which leads to high achievement, resulting in strong relational trust and academic optimism, and he proposes that these organizational features can help foster student achievement regardless of school SES. Consistently, Engin-Demir (2009) revealed that school characteristics that help schools to become positive environments for students are more important than family characteristics as predictors of academic achievement among low-SES urban students. In their study of schools facing socially and economically challenging circumstances in the UK, Potter, Reynolds, and Chapman (2002) underlined the role of the contribution of every individual at school, collaborative/mutual learning among all parties, effective leadership, effective data collection and use, and focusing on teaching and learning to improve schools, among other things. Similar implications can be drawn for Turkish schools facing similar 
challenges. Nearly all of the schools under study were either facing challenging circumstances or newly founded. These aspects may have affected educator perceptions and experiences of SI. Thus developing a guide or framework regarding improvement for such schools can be contributive in the Turkish context.

There was a strong emphasis on school physical capacity and characteristics as it was opined that these deeply affect what could be done at schools. Therefore, among the factors hindering improvement and suggestions to improve schools were enhancing the quality of school facilities and re-arranging them accordingly. Consistently, Uline and Tschannen-Moran (2008) found that the quality of school facilities affect student learning and achievement, and they proposed that if the school buildings are inadequate, the kind of community engagement exists there is less likely to undergird teaching and learning. In poor quality buildings, teachers are also less likely to show enthusiasm to make more efforts to support student learning. Likewise, according to Barrett, Treves, Shmis, Ambasz, and Ustinova (2019), school planning and design have strong impacts on the health and learning processes. They asserted that access to school places, safety and healthy schools, and optimal spaces for learning can contribute to student achievement, teacher retention, and community satisfaction.

One last point that requires attention is related to some specific problems faced at some schools. For a few schools, the large number of Syrian students was a problem which they believed stemmed from the imbalanced distribution of these students to public schools. Turkey has been hosting more than 3.6 million refugees from Syria and they are provided the right to attend public schools in Turkey. However, as most of them live in low SES areas in cities, there might be an intensive accumulation of refugees, which leads to a high number of Syrian refugees in neighboring schools as the student enrollment policy is based on student locations/addresses (Kalman \& işdar, 2019). Many problems including the language barrier, low SES among Syrians (Coşkun \& Emin, 2016), and physical inadequacies (Şahin \& Sümer, 2018) are faced in schools. Furthermore, some schools were far from the city center or located in a newly populated area or served as a transportation-centered school located in a district. Due to the school location, some problems were raised concerning SI. These were both remote and failed to attract successful students, based on the participant views. Therefore, novel school-level and district-level projects and studies may make these schools more attractive for all students. This issue has system-level reasons, though. Only a group of high schools accept students based on national exam results, which still holds a majority of students at nearby schools in Turkey.

The overall findings linked SI with several issues involving teachers, students, parents, school administrators, the organizational features of schools, school facilities, budget, and education system. These findings were mostly consistent with the prior work of Kondakçı and Sivri (2014) who detected that building and sharing a vision for achievement, constructing a positive learning environment, school leaders keeping abreast of their schools' needs and addressing them, positive school culture, monitoring student progress, the involvement of parents in schooling practices, structuring a safe physical environment and providing necessary materials are the key elements of gaining positive student outcomes. In a more recent study, Bozbayındır and Alev (2020) uncovered the importance of improving the quality of school facilities and providing sufficient resources. Also, the active participation of all of the stakeholders and the construction of a positive and trust-based school culture was found to be critical for the effective progression of educational activities. Robinson et al. (2017) underscored the importance of the presence of the capability to produce a well-coordinated effort for gaining sustainable results in achievement.

This study revealed that SI requires considering a wide range of aspects of schooling and can be achieved through the collaboration between and contributions of the staff, students, and parents, apart from some amendments in the education system. This is because $\mathrm{SI}$ is a collective attempt to ensure mutual learning and development of teachers and students (Harris, 2002), and it is not a road to walk straightforwardly. This research, inter alia, may indicate that the factors involving people, structure, and environment should be pondered upon to develop schools as none of them is an either/or, as indicated in the architecture of SI by Murphy (2013). For schools operating in centralized education systems, SI can be challenging due to the interaction of several dynamics at school and system levels. Although low SES, student attitudes, parental attitudes, teacher behaviors and practices, and lack of physical and financial capacity may have constraints on SI, each school must still make concerted efforts to develop. There are contextual factors which school administrators and teachers can act upon to improve schools such as forming a positive, supportive school climate and culture reinforced with solidarity, commitment, and collaboration. The transformation of cultural aspects of schools (Fullan, 2016) and positive organizational behavior can empower schools and systems to improve, even the ones facing challenging conditions. Without building a strong capacity as delineated in previous research, the efforts to improve schools will be like whistling in the wind.

Apart from the technical resources and finance, building a strong school capacity may necessitate taking effective steps to develop school administrators as effective leaders and teachers as effective learners to form a school community. Furthermore, since some external factors were observed to hinder SI as perceived by some participants, it can be suggested that the government take affirmative actions by providing more budget and resources to these schools to minimize the negative impacts of low SES on student outcomes, support and elevate them to a point at which they can work for improving student outcomes instead of dealing with the issues making no difference in student outcomes and damaging their socio-cultural ecology. SI requires a strong commitment to development; it is therefore critical to ensure the involvement of all stakeholders in the improvement process and make them believe in the need for improvement. All stakeholders' commitment to school-based policies, planning, and coordination may yield different results in SI.

\section{LIMITATIONS}

This research suffers from some limitations that should be considered while using the results obtained from the current research. The researcher used principals', vice-principals', and teachers' written answers about SI based on their perceptions and 
experiences. Only written answers were considered and analyzed; therefore, data triangulation was not possible. This may have limited seeing the wider contextual factors or underpinning issues that could have been revealed in interviews. The main limitation, however, is the lack of site-based research involving longitudinal observations and school data. The study was conducted with the enrolled educators; therefore, the number of teachers and principals was small, which also delimited making comparisons between school settings based on practitioners' perceptions and experiences. Most of the schools were understood to operate under challenging circumstances.

\section{REFERENCES}

Aldridge, J. M., Rijken, P. E., \& Fraser, B. J. (2020). Improving learning environments through whole-school collaborative action research. Learning Environments Research. Published on 6 June 2020. https://doi.org/10.1007/s10984-020-09318-x

Ateş, A., \& Ünal, A. (2019). Bir ortaokulda uygulanan okul geliştirme projesini anlamak: Bir durum çalışması [Understanding the school development project implemented in a secondary school: a case study]. Eğitimde Nitel Araştırmalar Dergisi-Journal of Qualitative Research in Education, 7(3), 1033-1061. https://doi.org/10.14689/issn.2148-624.1.7c.3s.6m

Barrett, P., Treves, A., Shmis, T., Ambasz, D., \& Ustinova, M. (2019). The impact of school infrastructure on learning: A synthesis of the evidence. Washington DC: The World Bank. https://doi.org/10.1596/978-1-4648-1378-8

Belenkuyu, C., Dulay, S., \& Aypay, A. (2020). Typologies of principals: School administration and routine works. Kuram ve Uygulamada Eğitim Yönetimi- Educational Administration: Theory and Practice, 26(1), $117-162$. https://doi.org/10.14527/kuey.2020.003

Bozbayındır, F., \& Alev, S. (2020). Okul yöneticilerinin okul gelişim modeli ile ilgili görüşleri [School administrators' views on the school development model]. OPUS-Uluslararası Toplum Araştırmaları Dergisi-OPUS-International Journal of Society Research, 15(24), 2640-2673. https://doi.org/10.26466/opus.667359

Braun, V., \& Clarke, V. (2006). Using thematic analysis in psychology. Qualitative Research in Psychology, 3(2), 77-101. https://doi.org/10.1191/1478088706qp063oa

Calp, Ş. (2020). Peaceful and happy schools: How to build positive learning environments?. International Electronic Journal of Elementary Education, 12(4), 311-320. https://doi.org/10.26822/iejee.2020459460

Coelli, M., \& Green, D.A. (2012). Leadership effects: School principals and student outcomes. Economics of Education Review, 31(1), 92-109. https://doi.org/10.1016/j.econedurev.2011.09.001

Constantinou, E., \& Ainscow, M. (2020). Using collaborative action research to achieve school-led change within a centralised education system: Perspectives from the inside. Educational Action Research, 28(1), 4-21. https://doi.org/10.1080/09650792.2018.1564686

Coşkun, I., \& Emin, M. N. (2016). A road map for the education of Syrians in Turkey: Opportunities and challenges. Ankara: SETA.

Creswell, J. W. (2013). Qualitative inquiry \& research design choosing among five approaches ( $3^{\text {rd }}$ ed.). Thousand Oaks, CA: Sage.

Desforges, C., \& Abouchaar, A. (2003). The impact of parental involvement, parental support and family education on pupil achievement and adjustment: Research report 433. London: Department for Education and Skills.

Engin-Demir, C. (2009). Factors influencing the academic achievement of the Turkish urban poor. International Journal of Educational Development, 29(1), 17-29. https://doi.org/10.1016/j.ijedudev.2008.03.003

Epstein, J. L. (2001). School, family and community partnerships. Boulder, CO: Westview Press.

Feldhoff, T., Radisch, F., \& Bischof, L. M. (2016). Designs and methods in school improvement research: A systematic review. Journal of Educational Administration, 54(2), 209-240. https://doi.org/10.1108/JEA-07-2014-0083

Fullan, M. (2016). The elusive nature of whole system improvement in education. Journal of Educational Change, 17(4), 539-544. https://doi.org/10.1007/s10833-016-9289-1

Fullan, M. (2020). The nature of leadership is changing. European Journal of Education, 55(2), $139-142$. https://doi.org/10.1111/ejed.12388

Garza, E., Drysdale, L., Gurr, D., Jacobson, S., \& Merchant, B. (2014). Leadership for school success: Lessons from effective principals. International Journal of Educational Management, 28(7), 798-811. https://doi.org/10.1108/IJEM-08-2013-0125

Gubbins, V., \& Otero, G. (2019). Parental involvement and low-SES children's academic achievement in early elementary school: New evidence from Chile. Educational Studies, 46(5), 548-569. https://doi.org/10.1080/03055698.2019.1620691

Han, J., \& Yin, H. (2016). Teacher motivation: Definition, research development and implications for teachers. Cogent Education, 3(1), 1217819. https://doi.org/10.1080/2331186X.2016.1217819

Harris, A. (2002). School improvement: What's in it for schools?. London: RoutledgeFalmer.

Harris, A. (2011). System improvement through collective capacity building. Journal of Educational Administration, 49(6), 624-636. https://doi.org/10.1108/09578231111174785

Harris, A. (2020). Leading school and system improvement: Why context matters. European Journal of Education, 55(2), $143-145$. https://doi.org/10.1111/ejed.12393

Harris, A., \& Jones, M. (2010). Professional learning communities and system improvement. Improving Schools, 13(2), $172-181$. https://doi.org/10.1177/1365480210376487 
Harrison, H., Birks, M., Franklin, R., \& Mills, J. (2017). Case study research: Foundations and methodological orientations. Forum Qualitative Sozialforschung/Forum: Qualitative Social Research, 18(1), Art. 19. Retrieved from http://nbnresolving.de/urn:nbn:de:0114-fqs1701195

Heck, R. H., \& Hallinger, P. (2014). Modeling the longitudinal effects of school leadership on teaching and learning. Journal of Educational Administration, 52(5), 653-681. https://doi.org/10.1108/JEA-08-2013-0097

Hopkins, D. (2001). School improvement for real. London: RoutledgeFalmer.

Hopkins, D., \& Reynolds, D. (2001). The past, present and future of school improvement: Towards the third age. British Educational Research Journal, 27(4), 459-475. https://doi.org/10.1080/01411920120071461

Hopkins, D., Harris, A., \& Jackson, D. (1997). Understanding the school's capacity for development: Growth states and strategies. School Leadership \& Management, 17(3), 401-412. https://doi.org/10.1080/13632439769944

Hoque, K. E., Alam, G. M., \& Abdullah, A. G. K. (2011). Impact of teachers' professional development on school improvement-An analysis at Bangladesh standpoint. Asia Pacific Education Review, 12(3), 337-348. https://doi.org/10.1007/s12564-010-9107-z

Hoy, W. (2012). School characteristics that make a difference for the achievement of all students: A 40-year odyssey. Journal of Educational Administration, 50(1), 76-97. https://doi.org/10.1108/09578231211196078

Ibrahim, A. (2020). What hurts or helps teacher collaboration? Evidence from UAE schools. Prospects, 1-18. Published on 28 January 2020. https://doi.org/10.1007/s11125-019-09459-9

Jeynes, H. W. (2005). A meta-analysis of the relation of parental involvement to urban elementary school student academic achievement. Urban Education, 40(3), 237-269. https://doi.org/10.1177/0042085905274540

Kalman, M., \& Işdar, S. (2019). Refugee integration into education and managerial challenges: An interview-based qualitative study. Paper presented at The Global Refugee and Migration Congress. 14-17 October, Gaziantep University, Turkey.

Kalman, M., Summak, M. S., \& Çimen, İ. (2017). Principal assignments in limbo: A qualitative study on the processes and potential outcomes of the recent principal assignment initiative in Turkey. Educational Process: International Journal, 6(1), 53-84. https://doi.org/10.22521/edupij.2017.61.4

Karadağ, E. (2020). The effect of educational leadership on students' achievement: A cross-cultural meta-analysis research on studies between 2008 and 2018. Asia Pacific Education Review, 21, 49-64. https://doi.org/10.1007/s12564-019-09612-1

Karadağ, E., İşçi, S., Öztekin, Ö., \& Anar, S. (2016). The relationship between school climate and students' academic achievement: A meta-analysis study. Inönü University Journal of the Faculty of Education, 17(2), $107-122$. https://doi.org/10.17679/iuefd.17294446

Kim, S.W. (2020). Meta-analysis of parental involvement and achievement in East Asian countries. Education and Urban Society, 52(2), 312-337. https://doi.org/10.1177/0013124519842654

King, M.B., \& Bouchard, K. (2011). The capacity to build organizational capacity in schools. Journal of Educational Administration, 49(6), 653-669. https://doi.org/10.1108/09578231111174802

Klein, E.D., \& Schwanenberg, J. (2020). Ready to lead school improvement? Perceived professional development needs of principals in Germany. Educational Management Administration \& Leadership, 1-21. Advance online publication. https://doi.org/10.1177/1741143220933901

Kondakçı, Y., \& Sivri, H. (2014). Salient characteristics of high-performing Turkish elementary schools. Journal of Educational Administration, 52(2), 254-272. https://doi.org/10.1108/JEA-12-2012-0136

Lee, M., \& Louis, K.S. (2019). Mapping a strong school culture and linking it to sustainable school improvement. Teaching and Teacher Education, 81, 84-96. https://doi.org/10.1016/j.tate.2019.02.001

Leithwood, K., Harris, A., \& Hopkins, D. (2020). Seven strong claims about successful school leadership revisited. School Leadership \& Management, 40(1), 5-22. https://doi.org/10.1080/13632434.2019.1596077

Leithwood, K., Sun, J., \& Schumacker, R. (2019). How school leadership influences student learning: A test of "the four paths model". Educational Administration Quarterly, 56(4), 570-599. https://doi.org/10.1177/0013161X19878772

Mincu, M. E. (2015). Teacher quality and school improvement: What is the role of research?. Oxford Review of Education, 41(2), 253269. https://doi.org/10.1080/03054985.2015.1023013

Mitchell, M. M., Bradshaw, C. P., \& Leaf, P. J. (2010). Student and teacher perceptions of school climate: A multilevel exploration of patterns of discrepancy. Journal of School Health, 80(6), 271-279. https://doi.org/10.1111/j.1746-1561.2010.00501.x

Mitchell, R. (2013). What is professional development, how does it occur in individuals, and how may it be used by educational leaders and managers for the purpose of school improvement?. Professional Development in Education, 39(3), $387-400$. https://doi.org/10.1080/19415257.2012.762721

MoNE. (2019). Turkey's education vision 2023. Retrieved on 25 June 2020 from http://2023vizyonu.meb.gov.tr/doc/2023_VIZYON_ENG.pdf

Murphy, J. (2013). The architecture of school improvement. Journal of Educational Administration, 51(3), $252-263$. https://doi.org/10.1108/09578231311311465

Nehez, J., \& Blossing, U. (2020). Practices in different school cultures and principals' improvement work. International Journal of Leadership in Education, 1-21. Advance online publication. https://doi.org/10.1080/13603124.2020.1759828 
Neuendorf, K. A. (2019). Content analysis and thematic analysis. In P. Brough (Ed.) Advanced research methods for applied psychology: Design, analysis and reporting. Abingdon, Oxon: Routledge. https://doi.org/10.4324/9781315517971-21

Oldaç, Y. I., \& Kondakçı, Y. (2019). Multilevel analysis of the relationship between school-level variables and student achievement. Educational Management Administration \& Leadership, 48(4), 762-780. https://doi.org/10.1177/1741143219827303

Özdemir, N., \& Yalçın, M. T. (2019). Ortaöğretim öğrencilerinin akademik başarısı ile okul ve öğrenci düzeyi değişkenler arasındaki ilişkilerin incelenmesi: Iki düzeyli yol analizi [Examining the relationship between academic achievement of secondary school students and school and student level variables: Two-level path analysis]. Eğitim ve Bilim- Education and Science, 44(200), 93116. https://doi.org/10.15390/EB.2019.8056

Poekert, P. E. (2012). Teacher leadership and professional development: Examining links between two concepts central to school improvement. Professional Development in Education, 38(2), 169-188. https://doi.org/10.1080/19415257.2012.657824

Potter, D., Reynolds, D., \& Chapman, C. (2002). School improvement for schools facing challenging circumstances: A review of research and practice. School Leadership \& Management, 22(3), 243-256. https://doi.org/10.1080/1363243022000020381

Robinson, V., Bendikson, L., McNaughton, S., Wilson, A., \& Zhu, T. (2017). Joining the dots: The challenge of creating coherent school improvement. Teachers College Record, 119(8), 1-44.

Saldaña, J. (2013). The coding manual for qualitative researchers (2nd ed.). Thousand Oaks, CA: Sage.

Sezgin, F., Koşar, D., Koşar, S., \& Er, E. (2016). Liselerde akademik başarısızlık: Nedenleri ve önlenmesine ilişkin öğretmen ve okul yöneticilerinin görüşleri. İnönü Üniversitesi Eğitim Fakültesi Dergisi, 17(1), 95-111. https://doi.org/10.17679/iuefd.17119535

Stake, R. (1995). The art of case study research. Thousand Oaks, CA: Sage.

Stolp, S., \& Smith, S.C. (1995). Transforming school culture: Stories, symbols, values \& the leader's role. ERIC Clearinghouse on Educational Management, University of Oregon.

Suna, H. E., Tanberkan, H., Gür, B. S., Perc, M., \& Özer, M. (2020). Socioeconomic status and school type as predictors of academic achievement. Journal of Economy Culture and Society, 61, 41-64. https://doi.org/10.26650/JECS2020-0034

Supovitz, J., D’Auria, J., \& Spillane, J. (2019). Meaningful \& sustainable school improvement with distributed leadership (\#RR 20192). Consortium for Policy Research in Education, University of Pennsylvania. Retrieved on 5 May 2020 from https://repository.upenn.edu/cpre_researchreports/112

Şahin, ì. (2013). Illköğretim okul müdürlerinin okul geliştirme stratejileri ve uygulamalarına ilişkin görüşleri [Primary school principals' views on school development strategies and practices]. Kuram ve Uygulamada Eğitim Bilimleri- Educational Sciences in Theory and Practice, 13(1), 229-250.

Şahin, S., \& Sümer, S. (2018). The problems experienced in the integration process of Syrian students into the Turkish education system. Universal Journal of Educational Research, 6(5), 909-918. https://doi.org/10.13189/ujer.2018.060512

Şeker, H. (2011). Developing a questionnaire on attitude towards school. Learning Environments Research, 14(3), $241-261$. https://doi.org/10.1007/s10984-011-9096-9

Şen, S., Yıldırım, I.., \& Karacabey, M. F. (2020). The implementation of the value-added assessment to determine school effectiveness. Education and Science, 45(202), 79-91. https://doi.org/10.15390/EB.2020.8023

Ten Bruggencate, G., Luyten, H., Scheerens, J., \& Sleegers. P. (2012). Modeling the influence of school leaders on student achievement: How can school leaders make a difference?. Educational Administration Quarterly, 48(4), 699-732. https://doi.org/10.1177/0013161X11436272

Thapa, A., Cohen, J., Guffey, S., \& Higgins-D’Alessandro, A. (2013). A review of school climate research. Review of Educational Research, 83(3), 357-385. https://doi.org/10.3102/0034654313483907

Uline, C., \& Tschannen-Moran, M. (2008). The walls speak: The interplay of quality facilities, school climate, and student achievement. Journal of Educational Administration, 46, 55-73. https://doi.org/10.1108/09578230810849817

Wang, M. T., \& Degol, J. L. (2016). School climate: A review of the construct, measurement, and impact on student outcomes. Educational Psychology Review, 28(2), 315-352. https://doi.org/10.1007/s10648-015-9319-1

Weddle, H., Lockton, M., \& Datnow, A. (2020). Teacher collaboration in school improvement. Oxford Bibliographies. https://doi.org/10.1093/OBO/9780199756810-0248

Xu, W., \& Zammit, K. (2020). Applying thematic analysis to education: A hybrid approach to interpreting data in practitioner research. International Journal of Qualitative Methods, 19, 1609406920918810. https://doi.org/10.1177/1609406920918810

Yalçın, M., Aypay, A., \& Boyacı, A. (2020). Principals' ordeal with bureaucracy. Kuram ve Uygulamada Eğitim Yönetimi- Educational Administration: Theory and Practice, 26(1), 203-260. https://doi.org/10.14527/kuey.2020.005

Yeigh, T., Lynch, D., Turner, D., Provost, S. C., Smith, R., \& Willis, R. L. (2019). School leadership and school improvement: An examination of school readiness factors. School Leadership \& Management, 39(5), 434-456. https://doi.org/10.1080/13632434.2018.1505718

Zepeda, S. J. (2013). Instructional leadership for school improvement. New York: Routledge. https://doi.org/10.4324/9781315852645

Zhu, C., Devos, G., \& Li, Y. (2011). Teacher perceptions of school culture and their organizational commitment and well-being in a Chinese school. Asia Pacific Educ. Rev., 12, 319-328. https://doi.org/10.1007/s12564-011-9146-0 